\title{
Membrane filtration in the study of antimicrobial drugs
}

\author{
P. D. MEERS AND GILLIAN M. CHURCHER
}

From the Hospital Microbiology and Public Health Laboratory, Greenbank Hospital, Plymouth, Devon

SYNOPSIS A membrane filtration apparatus of the type employed in water bacteriology was used in the assessment of some antimicrobial drugs. Samples of liquid nutrient medium inoculated with a small number of bacteria, to which dilutions of a drug had been added before incubation and again later, were filtered and the membranes washed and incubated on solid medium. By this means differences between bacteriostatic and bactericidal action were clearly demonstrated. It was shown that staphylococci which had survived exposure to penicillin or gentamicin at levels below their minimum bactericidal concentrations remained fully responsive to the subsequent addition of more of the same drug, while those which had survived exposure to chloramphenicol or clindamycin were not significantly affected by further addition, so that neither of the latter two drugs was bactericidal against the strain of organism used. Bactericidal effects were also demonstrated by benzyl penicillin against Clostridium welchii and ampicillin against Escherichia coli.

It is customary to distinguish between bacteriostatic and bactericidal drugs in vitro by subculturing from a nutrient medium containing a mixture of the drug and bacterium to a solid or liquid drug-free substrate which is then incubated to recover any viable organisms. Such a technique has the disadvantage that subculture of a small volume of the reaction mixture may fail to demonstrate a few residual bacteria, while subculture of a larger volume carries with it the probability of continued antibacterial acitivity due to carryover of the drug concerned. These difficulties are well recognized in testing disinfectants, where it is usual to try to overcome them by the use of chemical inactivators (Bergan and Lystad, 1972). This approach is not often possible with antibiotics and chemotherapeutic agents and apparently anomalous conclusions have sometimes been reached in connexion with the activities of these drugs. An example is the statement that clindamycin is bactericidal against Staphylococcus aureus (McGehee, Smith, Wilcox, and Finland, 1968) although the parent substance, lincomycin, is recognized as being bacteriostatic (Kaplan and Weinstein, 1965).

The technique of membrane filtration offers a solution to this problem, as it allows the sampling of large volumes of a reaction mixture. Any residual Received for publication 6 February 1974. viable organisms are deposited on the surface of the membrane where they can be washed free of the antimicrobial drug before culture. Membrane filtration apparatus of the type designed for the bacteriological examination of water supplies (Public Health Laboratory Service, 1969) can be used for this purpose. A study is described of the interaction of some anti-microbial drugs with a few bacterial species, making use of such an apparatus.

\section{Materials and Methods}

Ampicillin, benzylpenicillin, chloramphenicol, clindamycin, and gentamicin were tested against one or more of the following strains: Staph. aureus (NCTC 6571), Escherichia coli (NCTC 10418), and a recent clinical isolate of Clostridium welchii. The membrane filtration apparatus used was as recommended in report 71 (Public Health Laboratory Service, 1969), the filter holders being of stainless steel with a polypropylene collar and a sintered-glass filter bed on which was laid a cellulose membrane (Oxoid grade $0.45,4.7 \mathrm{~cm}$ diameter), previously sterilized by autoclaving. Six of these filter assemblies were set on a manifold of metal tubing, manufactured locally, and attached to a water filter pump. In the experiments to be described the funnels were freed from bacterial contamination 
by boiling in water for a few minutes between filtrations. (A larger number of filter assemblies could have been autoclaved, making this step unnecessary.)

The minimum inhibitory concentration (MIC) of each drug for each organism tested was determined in $1 \mathrm{oz}(28 \mathrm{ml})$ screw-capped bottles using $5 \mathrm{ml}$ of digest broth containing the drug diluted in twofold steps to cover the appropriate range. The bottles were inoculated and incubated at $37^{\circ} \mathrm{C}$ for $24 \mathrm{hr}$, and the MIC was read by recording the presence or absence of visual turbidity. The endpoint was the highest dilution in which there was no turbidity. The inoculum was $0.02 \mathrm{ml}$ of an overnight broth culture of the organism concerned diluted in quarter-strength Ringer's solution. The dilution chosen was usually $10^{-3}$ so as to give about 1000 organisms per $\mathrm{ml}$ in the reaction mixture. To confirm this a surface viable count (Miles, Misra, and Irwin, 1938) was made at the time the inoculum was added. The rather small inoculum was to avoid 'persisters' which might otherwise have interfered with the interpretation of bactericidal tests.

Simultaneously, duplicate bottles with the same dilutions of the antimicrobial drug were prepared, inoculated as described, and incubated at $37^{\circ} \mathrm{C}$ for six hours. Then the same quantity of the drug was added in $0.02 \mathrm{ml}$ to each bottle of this second set and incubation continued for a further 18 hours. This was arranged so that when allowance was made for dilution in the bottle, the additional quantity produced a concentration equal to a mean peak serum level expected in a patient on ordinary dosage of the drug. (The amount of drug added to each bottle of the duplicate set was in gross excess of that originally present in the majority of the bottles, with the exception of the first few bottles of some of the series, so that the difference in final concentration between the bottles in any one experiment was so small as to be insignificant.) A control uninoculated broth containing the highest concentration of drug used in the test was incubated under the same conditions.

After the MIC had been read $1 \mathrm{ml}$ of each reaction mixture was filtered through a membrane which was washed free of residual antibiotic by drawing through it two successive $10-20 \mathrm{ml}$ volumes of quarter-strength Ringer's solution. The membrane was then laid on blood agar or some other suitable medium and colony counts were made after 24 hours' aerobic or anaerobic incubation, depending on the organism used in the inoculum. One $\mathrm{ml}$ of the control uninoculated broth containing the highest concentration of drug used in the test was filtered through a membrane which was washed as described. One $\mathrm{ml}$ of a dilute suspension of the organism under test was filtered through this membrane and a similar quantity of the same bacterial suspension filtered through another membrane. The numbers of colonies developing after incubation on these were compared to see if any of the drug had been carrier over in the test by adsorption. The minimum bactericidal concentration (MBC) was the highest dilution of drug in a reaction mixture from which no colonies were obtained. The filtration process was repeated for the duplicate row of bottles to which additional drug had been added after six hours.

\begin{tabular}{|c|c|c|c|c|c|c|c|c|c|c|c|c|c|c|}
\hline & & \multicolumn{10}{|c|}{$\begin{array}{l}\text { Bottle Number } \\
\text { (with doubling dilutions of antibiotic) }\end{array}$} & \multirow[t]{2}{*}{$\begin{array}{l}\text { Drug Concentration in } \\
\text { Bottle } 1(\mu \mathrm{g} / \mathrm{ml})\end{array}$} & \multirow[t]{2}{*}{$\begin{array}{l}\text { No. of Organisms/ml } \\
\text { Reaction Mixture }\end{array}$} & \multirow{2}{*}{$\begin{array}{l}\text { Drug Added } \\
\text { to Filtration } \\
\text { (2 row } \mathrm{\mu g} / \\
\mathrm{ml})\end{array}$} \\
\hline & & 1 & 2 & 3 & 4 & 5 & 6 & 7 & 8 & 9 & 10 & & & \\
\hline \multirow[t]{3}{*}{ Benzylpenicillin } & Turbidity & - & - & - & - & - & - & - & + & + & + & \multirow{3}{*}{0.75} & \multirow{3}{*}{2500} & \multirow{3}{*}{$2 \cdot 0$} \\
\hline & Filtration 1 & - & - & - & - & - & - & 1 & C & C & C & & & \\
\hline & Filtration 2 & - & - & - & - & - & - & - & - & 1 & 32 & & & \\
\hline \multirow[t]{3}{*}{ Gentamicin } & Turbidity & - & - & - & - & - & - & - & - & + & + & \multirow{3}{*}{$4 \cdot 0$} & \multirow{3}{*}{1400} & \multirow{3}{*}{$8 \cdot 0$} \\
\hline & Filtration 1 & - & - & - & - & 62 & 27 & 76 & 600 & SC & $\mathbf{C}$ & & & \\
\hline & Filtration 2 & - & - & - & - & - & - & - & - & - & - & & & \\
\hline \multirow[t]{2}{*}{ Chloramphenicol } & Turbidity & - & - & - & - & - & - & - & + & + & + & \multirow[b]{2}{*}{$50 \cdot 0$} & & \multirow[b]{2}{*}{40.0} \\
\hline & $\begin{array}{l}\text { Filtration } 1 \\
\text { Filtration } 2\end{array}$ & $\begin{array}{l}113 \\
101\end{array}$ & $\begin{array}{l}158 \\
243\end{array}$ & $\begin{array}{l}400 \\
400\end{array}$ & $\begin{array}{l}600 \\
400\end{array}$ & $\begin{array}{l}\text { SC } \\
\text { SC }\end{array}$ & $\begin{array}{l}\text { SC } \\
\text { SC }\end{array}$ & $\begin{array}{l}\mathrm{C} \\
\mathrm{SC}\end{array}$ & $\begin{array}{l}\text { C } \\
\text { SC }\end{array}$ & $\begin{array}{l}\mathrm{C} \\
\mathrm{SC}\end{array}$ & $\begin{array}{l}\mathrm{C} \\
\mathrm{SC}\end{array}$ & & 1220 & \\
\hline Clindamycin & $\begin{array}{l}\text { Turbidity } \\
\text { Filtration } 1 \\
\text { Filtration } 2\end{array}$ & $\begin{array}{r}- \\
60 \\
46\end{array}$ & $\begin{array}{l}- \\
71 \\
44\end{array}$ & $\begin{array}{l}- \\
96\end{array}$ & $\begin{array}{r}- \\
105 \\
82\end{array}$ & $\begin{array}{r}- \\
103 \\
80\end{array}$ & $\begin{array}{r}- \\
162 \\
76\end{array}$ & $\overrightarrow{S C}$ & $\begin{array}{l}+ \\
\mathbf{C} \\
300\end{array}$ & $\begin{array}{l}+ \\
\text { SC }\end{array}$ & $\begin{array}{l}+ \\
\text { C } \\
\text { SC }\end{array}$ & $3 \cdot 8$ & 1460 & $8 \cdot 0$ \\
\hline
\end{tabular}

Table I Results of determinations of minimum inhibitory concentrations of four drugs against Staphylococcus aureus (NCTC 6571)

${ }^{1}$ Results were read by the development of turbidity in broth after 24 hours at $37^{\circ} \mathrm{C}$ and of the minimum bactericidal concentrations (where possible) by filtration of $1 \mathrm{ml}$ of the reaction mixture (filtration 1) or of $1 \mathrm{ml}$ of the reaction mixture in an otherwise identical set of bottles to which had been added additional antibiotic after six hours' incubation (filtration 2) and the counting of any colonies developing from viable residual organisms

$+=$ turbid, $-=$ no turbidity or nil colony count

$\mathbf{C}=$ confluent growth; $\mathbf{S C}=$ semi confluent growth

A number, unless otherwise specified $=$ number of colonies developing; figures $>300$ are approximate 
Table II Results of estimations of the minimum inhibitory and bactericidal concentrations of two of the penicillins against the organisms named determined as in table I

'Addition at 24 hours.

For key, see table I.

\section{Results}

Table I records the results of some experiments of the type described, in which four antibiotics were tested against Staph. aureus. Three sets of results are presented for each drug, the first a reading of the MIC, the second the MBC, and the third the same as the second, except that they were derived from the separate though originally identical set of reaction mixtures to which 'peak serum levels' of the same drug had been added after six hours' incubation. Appropriate negative and positive controls were included in each case, and no adsorption of any of the drugs to filter membranes was demonstrated. It could be argued that potentially viable cells whose walls had been weakened by an antibiotic like penicillin might be damaged further by washing with a liquid of low osmotic pressure such as quarter-strength Ringer's solution. In consequence, the experiment with benzylpenicillin was repeated and the membranes were washed with sterile nutrient broth of the same osmolarity as that in the reaction mixture. This did not alter the results. Details of more experiments of the same type are given in table II, where the interactions of ampicillin with Esch. coli and benzyl penicillin with $\mathrm{Cl}$. welchii are recorded.

Although the size of the bacterial population involved makes the development of resistance during an experiment unlikely, in a few of the experiments the sensitivity of residual organisms taken from a membrane was compared with that of the inoculum originally used. In no case was any difference found between the sensitivity of strains before and after their exposure to the drug.

\section{Discussion}

Table I shows an obvious and striking difference between benzylpenicillin and gentamicin on the one hand and chloramphenicol and clindamycin on the other. Not only did the first two show a close or very close relationship between their MIC and MBC, but the addition of a second dose of drug after six hours, an interval commonly used in therapy, had a profound effect on organisms which bad not been killed by the drug originally present. Thus organisms surviving from among a population diminished but not extinguished by levels of penicillin or gentamicin below their MBC remain fully susceptible to further attack by the same drug. The classification of penicillin and gentamicin as bactericidal for the staphylococcus is upheld by these experiments, which are extended in table II to the action of penicillins against two other organisms. Chloramphenicol and clindamycin, however, showed no evidence of an MBC at levels up to 64 times their MIC, and perhaps more significantly the addition of a further drug at six hours made little difference to those organisms which had not been killed by the drug originally present. Chloramphenicol has always been regarded as being bacteriostatic; clindamycin joins it under this description in its action against this strain of $\frac{\mathrm{O}}{9}$ Staph. aureus.

Membrane filtration is a useful method for examining the antimicrobial activity of antibiotics and similar substances, as it allows growth and 0 enumeration of surviving organisms freed from the $N$ original toxic material or from complex neutralizing $\underset{\omega}{N}$ agents. It can be applied to kinetic studies and to studies of drug mixtures (Meers, 1973) as well as toco studies of single drugs under various states of nutrition of the target organism. It might also be ${ }^{+}$ used to study the sensitivity of clinical isolates, in $\frac{0}{0}$ cases of bacterial endocarditis, to antimicrobial $\frac{}{\mathbb{D}}$ drugs used alone or in combination. In such cases $\frac{\widetilde{\rho}}{\mathbb{D}}$ larger inocula might be employed, so as to take $\varrho$ account of the effect of persisters. 


\section{References}

Bergan, T., and Lystad, A. (1972). Evaluation of disinfectant inactivators. Acta path. microbiol. scand., Sect. B, 80, 507-510.

Kaplan, K., and Weinstein, L. (1965). Lincomycin. Practitioner, $194,834-840$.

McGehee, R. F., Jr., Smith, C. B., Wilcox, C., and Finland, M. (1968). Comparative studies of antibacterial activity in vitro and absorption and excretion of lincomycin and clinimycin. Amer. J. med. Sci., 256, 279-292.

Meers, P. D. (1973). Bacteroides infections. Lancet, 2, 573.

Miles, A. A., Misra, S. S., and Irwin, J. O. (1938). The estimation of the bactericidal power of the blood. J. Hyg. (Lond.), 38, 732749.

Public Health Laboratory Service (1969). The bacterological examination of water supplies. Rep. Publ. Hlth med, Subj., 71,

\section{The March 1974 Issue}

\section{THE MARCH 1974 ISSUE CONTAINS THE FOLLOWING PAPERS}

Hypothalamic regulatory hormones: A review G. M. BESSER AND C. H. MORTIMER

An assessment of one year of computer-assisted microbiology reporting at Charing Cross Hospital H. J. ANDREWS AND M. VICKERS

Activity of FL 1060 , a new $\beta$-lactam antibiotic, against urinary tract pathogens $D$. GREENWOOD, H. LINTON BROOKS, R. GARGAN, AND F. O'GRADY

Serum IgM and IgA responses in influenza $A$ infections G. E. D. URQUHART

A morphological assessment of immunoreactivity in colonic Crohn's disease and ulcerative colitis by a study of the lynph nodes J. M. SKINNER AND R. WHITEHEAD

Experience with a cholinesterase histochemical technique for rectal suction biopsies in the diagnosis of Hirschsprung's disease P. H. TRIGG, R. BELIN, S.HABERKORN, W. J. LONG, H. H. NIXON, J. PLASCHKES, L. SPITZ, AND G. H. WILLITAL

Malignant haemangioendothelioma involving the liver STELla M. POLLARD AND G. H. MILLWARDSADLER

An automated micromethod for measuring iron concentration in serum using thioglycollic acid and bathophenantroline sulphonate B. BROzOVIĆ AND YVONNE PURCELL
The cerebrospinal fluid in acute leukaemia of childhood: studies with the Cytocentrifuge D. I. K. EVANS, COLLEEN O'ROURKE, AND PATRICIA MORRIS JONES

The bone marrow in aplastic anaemia: Diagnostic and prognostic features B. FRISCH AND S. M. LEWIS

Cyclic thrombocytopenia: A thrombopoietin deficiency? M. L. LEWIS

The estimation of haemoglobin $\mathrm{A}_{2}$ : ls visual assessment reliable? G. I YAWSON, H. FESSAS, F. E. BOULTON, R. G. HUNTSMAN, AND I. S. MENZIES

Heparin therapy: A simpler test of control ANTHONY J. HANDLEY

\section{Technical methods}

Modification of an incident light microscope for fluorescence D. J. LEA AND D. J. WARD

Improved mountant for immunofluorescence preparations G. V. HEIMER AND C. E. D. TAYLOR

Symposium on Anticoagulant Control L. POLLER

Letters to the Editor

Book reviews

Copies are still available and may be obtained from the PUBLISHING MANAGER, BRITISH MEDICAL ASSOCIATION, TAVISTOCK SQUARE, LONDON WC1H 9JR, price $£ 1.05$ 